\title{
SEMANTIC CATEGORIES OF REPORTING VERBS IN ONLINE NEWS ARTICLES
}

\author{
Ruminda \\ Fakultas Adab dan Humaniora \\ UIN Sunan Gunung Djati Bandung \\ Email: adnimur@gmail.com
}

\begin{abstract}
Reporting as a feature of a news genre has been an interesting research for many language researchers currently. As the use of the media in reporting other people's ideas becomes more vary, the focus of the research is widely developed. One of the interesting reporting devices to analyze is the reporting verbs which have the main function of reporting other's statements. This article will analyze the semantic categories of these verbs used in news articles published in 4 online news media. The theories from Biber, et al. (2002) equipped by Quirk (1985) are applied to analyze this problem. The findings show that there are three semantic categories found in the reporting verbs used in online news article. Those are classified into communication, activity, and mental verbs.
\end{abstract}

Keywords: reporting, reporting verbs, semantic categories, online news articles

\begin{abstract}
ABSTRAK
Pelaporan sebagai sebuah fitur penulisan berita telah menjadi objek penelitian yang menarik bagi banyak peneliti bahasa akhir-akhir ini. Semakin banyaknya media yang digunakan untuk menyampaikan ide seseorang, semakin berkembang pula fokus penelitian dalam penelitian ini. Salah satu alat pelaporan yang menarik untuk dibahas adalah verba pelaporan yang fungsi utamanya adalah menyatakan kembali pernyataan orang lain. Artikel ini akan membahas kategori-kategori semantik verba pelaporan yang digunakan dalam artikel berita yang dimuat dalam 4 media berita daring. Teori dari Biber, et al. (2002) yang dilengkapi oleh teori dari Quirk (1985) digunakan untuk membahas masalah ini. Hasil analisis menunjukkan bahwa ada tiga kategori semantik yang ditemukan dalam penggunaan verba pelaporan di artikel berita media daring. Ketiga kategori ini dibedakan menjadi tiga jenis verba, yaitu verba komunikasi, verba aktivitas dan verba mental.
\end{abstract}

Kata kunci: pelaporan, verba pelaporan, kategori semantik, artikel berita media berita daring

\section{INTRODUCTION}

Reporting is one of the linguistic phenomena in writing. In academic writing, this term is mostly found to give the report of some previous research, give comment or cite some important quotations take from the previous source. Reporting discourse is generally divided into two kinds, direct and indirect (Sakita, 2002:173). However, Zhang (2008:4) said that there are significant differences between 
the term reporting in academic writing and reported speech. Reporting in academic writing refers to how the academic writers refer to the previous studies or the result of the research, while reported speech is used to report what has been said by its speaker. In other words, reported speech is studied in the relation between written and spoken discourse, while reporting is the term used for only written discourse. In this research, the term reporting is used as a feature of reporting others' idea while reported speech refers to the form of reporting both direct and indirect.

There are three functions of reporting Weissberg and Buker (1990:41) purposed, first, giving readers background information about your study; second, showing readers your familiarity with the area; third, establishing your study as one link in a chain of research that is developing and enlarging knowledge in your field.

News report is one of the forms which uses reported speech in reporting the statements given by the news source. News report published as a news article in media currently becomes the interesting object to discuss since it has many perspectives to be analyzed. One of the topics which is interesting to discuss in news report is the reporting verbs. Zhang (2008:5) said that reporting verbs are among those which can be identified as reporting signal besides reporting noun phrase, reporting adjectives, and reporting adjuntc (including reporting adverbs, prepositional phrase, and subordinative finite clause). Bergler (1992:5) said that reporting verbs can also create the intentional context for the complement with verbs of cognition.

Reporting verbs are the most important features of a reporting clause and occur in most reporting sentences (Nkansah, 2013:2). Thompson and Ye
(1991) said that reporting verbs enable a writer to express their own evaluation towards what is being reported.

Reporting verbs in news articles become important to discuss because they give a deeper meaning to the report, not only to the evaluation function but also to the evidentiality. Many newspaper articles consist of up to $90 \%$ reported speech sentences (Bergler, 1992:4) which means that the use of reporting verbs in news articles is also many.

In a sentence structure, a reporting verb fills the position as the verb, the same way as the other kinds of verb. What makes it differ from the other verbs is in the meaning it has, which is to inform. To know whether a verb is a reporting verb or not, a deep understanding to the sentence is needed. This understanding will be gained from the analysis of semantic behavior of the verb to find the semantic category of it.

Verbs

Verb is one of the syntactic categories that has an important part in a sentence. In an English sentence, a verb usually appears as one of the elements in predicate.

Semantically, a verb shows an activity, a state, or a process. In line with this, Celce-Murcia \& LarsenFreeman also said that a verb is "a word that denotes an action or state of being" (1999:16).

Generally, verbs are divided into two types, lexical and auxiliary verbs. A lexical verb is the head of a verb phrase because it is the main content of the meaning. Meanwhile, an auxiliary verb functions to help the lexical verb by adding some grammatical elements to mark the tense, voice, mood, and aspect, or by marking the negative and interrogative sentences, or adding the semantic meaning of a modality (Frank, 1972:50). 
From its semantic behavior, Biber, et al. (2002) divides the lexical verb into seven semantic categories, those are activity verbs, communication verbs, mental verbs, causative verbs, verbs of occurence, verbs of existence or relationship, and verbs of aspect. (106)

1. Activity verbs refer to a volitional activity, that is, an action performed intentionally by an agent or 'doer' (e.g. run, give, move).

2. Communication verbs are a special subcategory of activity verbs that involve communication activities, particularly verbs describing speech and writing. Most of the verbs for reporting are in this category. (e.g. say, shout, ask)

3. Mental verbs refer to mental states and activities (e.g. think, know, decide)

4. Causative verbs indicate that some person or thing helps to bring about a new state of affairs (e.g. allow, cause, force)

5. Verbs of occurrence report events that occur without an actor (e.g. become, grow, change).

6. Verbs of existence or relationship report a state of existence or a logical relationship that exists between entities (e.g. appear, seem, contain)

7. Verbs of aspect characterize the stage of progress of an event or activity (e.g. keep, begin, start).

In addition, for the purpose of the research, the division of verbs from Quirk, et al. (1985) is also applied. Quirk, et al. (1985:1180) divides the verbs into two classes, major and minor classes. There are two types of verbs in major class, factual and suasive verbs, and there are two types ini minor classes, emotive and hypothesis verbs.

a. Major class

(1) Factual verbs are verbs which are associated with the expression of speech acts concerned with statement. This type is subdivided into public (speech act verbs introducing indirect statement, e.g. agree, say, claim) and private (factual verbs expresses intellectual states such as belief and intellectual acts such as discovery, e.g. believe, imagine)

(2) Suasive verbs are verbs which are associated with directives, e.g. suggest.

b. Minor class

(1) Emotive verbs, e.g. regret, marvel, rejoice, wonder

(2) Hypothesis verbs, e.g. wish, suppose

\section{Reporting Verbs}

Bergler (1992:9), in a narrow interpretation, defined reporting verbs as the verbs used to convey the language of others. In a wider view, reporting verbs are those verbs that report the speech of others. CelceMurcia\&Larsen-Freeman (1992:9) said that reporting verbs are the verbs in a context which functions to give comment on others' statement or thought. The examples of the use of reporting verbs are as follow:

(1) The President said, 'A failure by Congress to approve new taxes will lead to larger budget deficits, higher interest rates, and higher unemployment.' 
(2) Smith claimed that during this/that recession, there would be no reduction in school budgets.

Both sentences in (1) and (2) use say and claim as their reporting verbs. Sentence (1) is in the form of direct sentence (direct speech) and sentence (2) is indirect sentence (indirect speech). Say is said as the most unmarked reporting verb because the use of this verb does not denote the position of the speaker. Meanwhile, the claim lexically gives more specific meaning than say. Claim means 'to state or declare something as a fact without being able to prove it'. In this case, the word claim will give more doubt since there is no fact to prove the truth. This problem shows that the choice of reporting verbs in a news article will show something more than its lexical meaning and the semantic category of the reporting verbs will help the reader to understand the content of the meaning inside the verbs.

\section{Previous Studies on Reporting Verbs}

A lot of studies have been conducted in analyzing the reporting verbs. Among the previous studies are the those who analyzed the categories of reporting verbs in academic discourse (Malcolm 1987; Shaw 1992; Thompson and Ye 1991; Thomas \& Hawes 1994; Hyland 1999), the tense usage of reporting verbs (Oster 1981; Een 1982; Hanania \& Akhtar 1985; Malcolm 1987; Swales 1990; Shaw 1992).

However, relatively few studies discuss the reporting verbs used in news articles. Some of the few researchers who focused on the newspaper as their object of the research are Bergler (1991) who studied the evidential analysis of reported speech in newspaper articles by using corpus data analysis, Yamashita (1998) who studied the contrastive analysis of discourse representation in American and Japanese newspaper reports, Kakavoulia \& Politis (2010) who studied indirect discourse in Greek news articles, focusing on the voices and reporting verbs, and Nkansah (2013) who analyzed reporting verbs and stance in Ghanaian newspaper.

From the perspective of semantic categories, Thompson and Ye's (1991) research has become the most notable early research. In their discussion, they distinguished three categories of reporting verbs used in academic papers according to the activities they perform: textual (verbs with verbal expression), mental (verbs refer to mental processes), and research (verbs refer to the process that are part of research activity).

This research will focus on the semantic categories of reporting verbs used in online news articles. There will some differences with the previous studies since the object of the research is news articles. There hasn't been any research focusing on the category of the reporting verbs in news article yet.

\section{METHODOLOGY Research Design}

A method is what a research needs to make the data analysis well organized and analyzed. A research method is a device, procedure, and technique chosen to conduct the research (Djajasudarma, 2006:2). For the purpose of this research, a qualitative method is found very useful to solve the problem. A qualitative method used in a research is any method for doing a research that uses general observations, depth and verbal description in place of numerical measures (Priest, 1996). 
The qualitative content analysis method applies the subjective interpretation of the content of text data through the systematic classification process. This method goes beyond the words or objective content from texts to examine meaning. It allows researchers to depict and understand social reality in a subjective but scientific manner.

The data used in this qualitative research focuses on descriptive data which, then, will be described and explained by the researcher. This descriptive qualitative method is mostly done for language research.

\section{Source of Data}

The data in this research are taken from 4 (four) online media. The data taken are in the form of reported speech found in the news articles. The online media used here as the sources of data are The Jakarta Post, New York Times, BBC, and $C N N$. These media are selected purposively since they have great amount of readers and also many achievements. The online version is chosen since the online technology becomes more popular and is able to send the information very quickly to all parts of the world.

The Jakarta Post is a daily English language newspaper in Indonesia. The paper was one of the few Indonesian English-language dailies to survive the 1997 Asian financial crisis and currently has a circulation of about 40,000. It is targeted at foreigners and educated Indonesians, although the middle-class Indonesian readership has increased. Noted for being a training ground for local and international reporters, The Jakarta Post has won several awards and been described as being "Indonesia's leading English-language daily. The Jakarta Post features an online edition, which includes both print and internet exclusive stories that are free to access. (Wikipedia)

$$
\text { The New York }
$$

Times (sometimes abbreviated to NYT) is an American daily newspaper, founded and continuously published in New York City since September 18, 1851, by the New York Times Company. The New York Times has won 117 Pulitzer Prizes, more than any other news organization. The New York Times has had a presence on the Web since 1996, and has been ranked one of the top websites. (Wikipedia)

CNN launched its website, CNN.com (initially an experiment known as CNN Interactive), on August 30, 1995. The site attracted growing interest over its first decade and is now one of the most popular news websites in the world. The widespread growth of blogs, social media and user-generated content have influenced the site, and blogs in particular have focused CNN's previously scattershot online offerings, most noticeably in the development and launch of CNN Pipeline in late 2005. In April 2009, CNN.com ranked third place among online global news sites in unique users in the U.S., according to Nielsen/NetRatings; with an increase of $11 \%$ over the previous year. (Wikipedia)

BBC Online, formerly known as $\mathbf{B B C} \mathbf{i}$, is the brand name and home for theBBC's UK online service. It is a large network of websites including such high profile sites as BBC News and Sport, the on-demand video and radio services co-branded $\mathrm{BBC}$ iPlayer, the pre-school site CBeebies, and learning services such as Bitesize. The BBC has had an online presence supporting its TV and radio programmes and web-only initiatives since 1994 but did not launch officially until December 1997, following government approval to fund it by TV 
license fee revenue as a service in its own right. Throughout its short history, the online plans of the $\mathrm{BBC}$ have been subject to harassment from its commercial rivals, which has resulted in various public consultations and government reviews to investigate their claims that its large presence and public funding distorts the UK market. (Wikipedia)

\section{Technique of Collecting Data}

There are 21 news articles selected randomly with different topics used in this research. These articles are collected from 4 (four) online media by copying them from their websites. There are 8 news articles taken from The Jakarta Post, 4 news articles from New York Times, 4 news articles rom $\mathrm{BBC}$, and 5 news articles from $\mathrm{CNN}$. The articles then are selected by giving mark on the reported speech found. The reporting verbs in each reporting sentence are marked and their meanings are looked up from a dictionary. These verbs, then, are classified based on the same core meaning and categorized using the theory of Biber, et al. (2002) and Quirk (1985).

\section{Technique of Analyzing Data}

The classified data are next analyzed by their literal meanings and put them to the same category. The categorized data, then, are analyzed to find the private or public meaning explained by Quirk (1985). The last step in this data analysis is concluding, in which the researcher will conclude the result of the analysis.

\section{FINDING AND DISCUSSION}

\section{Finding}

\section{a. Reporting Verbs Found}

From 21 news articles published in 4 online news media, the reporting verbs found are as follow:

Table 1: The Number of Reporting Verbs found in Online News Media

\begin{tabular}{|l|c|c|}
\hline $\begin{array}{c}\text { Online } \\
\text { news } \\
\text { media }\end{array}$ & $\begin{array}{c}\text { Number } \\
\text { of } \\
\text { articles }\end{array}$ & $\begin{array}{c}\text { Number of } \\
\text { reporting } \\
\text { verbs found }\end{array}$ \\
\hline $\begin{array}{l}\text { The Jakarta } \\
\text { Post }(\text { TJP })\end{array}$ & 8 & 28 \\
\hline $\begin{array}{l}\text { New York } \\
\text { Times }(\text { NYT) }\end{array}$ & 4 & 34 \\
\hline CNN & 4 & 27 \\
\hline BBC & 5 & 19 \\
\hline
\end{tabular}

From the table above, it is shown that New York Times uses more variety of reporting verbs than the other online media with approximately 8 different reporting verbs in each article. $C N N$ uses about 7 different reporting verbs in each article, $B B C$ uses about 4 different reporting verbs, while The Jakarta Post, although this research used the most number of its article, only uses about 3 different reporting verbs in each article. The more variety of using different reporting verbs shows that the news reporters is more expressive in reporting the news since they are able to express different situation gained from the context of the sentence given by the news source as their original speaker.

Table 2: Reporting Verbs Identified

\begin{tabular}{|l|l|}
\hline $\begin{array}{c}\text { Online } \\
\text { News } \\
\text { Media }\end{array}$ & \multicolumn{1}{|c|}{ Reporting Verbs } \\
\hline$T J P$ & $\begin{array}{l}\text { say, claim, tell, quote, report, } \\
\text { confirm, refuse, announce, } \\
\text { advice, decline, sentence, } \\
\text { deny, explain, add, agree, } \\
\text { speak, suggest, accuse, } \\
\text { conclude, reveal, list, give, } \\
\text { prove, find, estimate, expect, } \\
\text { decide, believe }\end{array}$ \\
\hline$N Y T$ & $\begin{array}{l}\text { say, vow, warn, offer, echo, } \\
\text { impose, decline, insist, argue, }\end{array}$ \\
\hline
\end{tabular}




\begin{tabular}{|l|l|}
\hline $\begin{array}{c}\text { Online } \\
\text { News } \\
\text { Media }\end{array}$ & \multicolumn{1}{|c|}{ Reporting Verbs } \\
\hline & $\begin{array}{l}\text { speak, confirm, claim, } \\
\text { interject, agree, made clear, } \\
\text { acknowledge, tell, complain, } \\
\text { call, pledge, ask, demonstrate, } \\
\text { reach, show, point, issue, } \\
\text { bristle, prove, note, expect, } \\
\text { think, assume, hope }\end{array}$ \\
\hline$C N N$ & $\begin{array}{l}\text { say, describe, claim, add, tell, } \\
\text { speak, speak, argue, made the } \\
\text { comment, doubt, respond, }\end{array}$ \\
\hline$B B C$ & $\begin{array}{l}\text { say, report, criticise, offer, } \\
\text { tell, suggest, announce, quote, } \\
\text { add, warn, deny, post, capture, } \\
\text { release,show, give, call on, } \\
\text { believe, expect }\end{array}$ \\
\hline
\end{tabular}

As in the frequency of occurence, the reporting verb say is in the first position with the highest number of occurence compared with the other reporting verbs. The table below will show the number of occurence of each reporting verb found in all 21 articles.

Table 3: Number of Occurrence

\begin{tabular}{|l|c|}
\hline Reporting Verbs & Frequency \\
\hline Say & 196 \\
\hline Tell & 20 \\
\hline add, quote, show & 8 \\
\hline Report & 6 \\
\hline Claim & 5 \\
\hline decline, warn & 4 \\
\hline speak, suggest, believe & 3 \\
\hline $\begin{array}{l}\text { announce, deny, give, } \\
\text { expect, find, list }\end{array}$ & 2 \\
\hline $\begin{array}{l}\text { accuse, argue, confirm, } \\
\text { made the comments, } \\
\text { respond, sentence, decide, } \\
\text { doubt, note, call, capture, } \\
\text { demonstrate, issue, offer, } \\
\text { post, prove, }\end{array}$ & 1 \\
\hline $\begin{array}{l}\text { ask, assume, back up, } \\
\text { complain, conclude, }\end{array}$ & \\
\hline
\end{tabular}

\begin{tabular}{|l|l|}
\hline Reporting Verbs & Frequency \\
\hline criticise, describe, echo, & \\
elaborate, explain, feature, & \\
impose, insist, interject, & \\
made clear, made similar & \\
assertions, call, pledge, & \\
point, refuse, vow, & \\
consider, estimate, focus, & \\
think, weigh, bristle, & \\
reach, release & \\
\hline
\end{tabular}

From table 3, it is clear that say is the most common reporting verb and mostly used in the news articles. As it is said before that this word is the most unmarked reporting verb which does not show the position of the speaker in delivering the utterance. Semantically, this word tends as a neutral word since it can be used in every situation without noticing the context of the speaker.

\section{b. Semantic Category}

In analyzing the semantic category of the reporting verbs found, the reporting verbs found in the data are classified into the semantic categories proposed by Biber (2002) and found three categories: activity, communication, and mental verbs.

Table 4: The Semantic Category of Reporting Verbs Found

\begin{tabular}{|l|c|c|c|c|}
\hline $\begin{array}{l}\text { Semantic } \\
\text { Category }\end{array}$ & TJP & NYT & $\boldsymbol{C N N}$ & $\boldsymbol{B B C}$ \\
\hline Activity & 4 & 7 & 10 & 6 \\
\hline $\begin{array}{l}\text { Communi } \\
\text { cation }\end{array}$ & 19 & 21 & 14 & 11 \\
\hline Mental & 5 & 6 & 3 & 2 \\
\hline \multicolumn{5}{|c|}{ Moreover, the division of public }
\end{tabular}

and private verbs from Quirk (1985) is also applied to analyze the data to find the content of the verbs. From the data, the types of public and private verbs of the reporting verbs found are as follow: 
Table 5: Public and Private Verbs of Reporting Verbs Found

\begin{tabular}{|l|c|c|}
\hline \multirow{2}{*}{$\begin{array}{c}\text { Online News } \\
\text { Media }\end{array}$} & \multicolumn{2}{c|}{ Types of RV } \\
\cline { 2 - 3 } & Public & Private \\
\hline The Jakarta Post & 18 & 10 \\
\hline New York Times & 21 & 13 \\
\hline CNN & 13 & 14 \\
\hline BBC & 11 & 8 \\
\hline
\end{tabular}

\section{Discussion}

The purpose of this research is to find the semantic category of the reporting verbs found in news articles published in online media. From the data, there are three semantic categories found, activity verbs, communication verbs, and mental verbs. The discussion of the three semantic categories found are as follow.

A. Activity verbs

As explained by Biber, et al. (2002) activity verbs refer to the action performed by the doer. The following examples show the activity verbs used as reporting verbs in the news article:

1. Right-wing bikers demonstrated outside the country's only refugee relocation facility in July, and earlier this month it was burned to the ground. (NYT, 120915)

The word demonstrate in this sentence is the reporting verb which means take part in a public rally as a protest or to show support. Here, the semantic feature of the word demonstrate is [show support+public]. Here, the right-wing bikers become the doer for this activity. This verb belongs to 'public' verb since the verb 'demonstrate' is publicly observable.

2. The government recently gave a nod to Bulog to import 328,000 tons of white sugar for household consumption to meet a shortage of 340,000 tons. (TJP, 300414)

The verb in phrase gave a nod is the reporting verb in this sentence. This phrase denotes what someone does to show his agreement [show+agree]. In this sentence, the doer is 'the government' which reflects the representative of people governing a country. This word belongs to 'public' types because it is shown publicly.

3. Dramatic dashcam images show the TransAsia passenger plane clipping a bridge as it plunges towards the river. (BBC, 060215)

In this sentence, the word show is the reporting verb. Show means cause something to be seen. It reports the activity happened to the subject 'dramatic dashcam images'. The verb also belongs to 'public' category.

Besides the three activity verbs discussed above, the table below will show the activity verbs found in data.

Table 6: Activity Verbs in News Article

\begin{tabular}{|l|l|}
\hline $\begin{array}{c}\text { Online } \\
\text { News } \\
\text { Media }\end{array}$ & \multicolumn{1}{|c|}{ Activity Verbs } \\
\hline$T J P$ & reveal, list, give, prove, find \\
\hline$N Y T$ & $\begin{array}{l}\text { demonstrate, reach, show, } \\
\text { point, issue, bristle, prove }\end{array}$ \\
\hline$C N N$ & $\begin{array}{l}\text { focus, find, show, feature, } \\
\text { capture, post, call for, issue, } \\
\text { list, back up }\end{array}$ \\
\hline$B B C$ & $\begin{array}{l}\text { post, capture, release, show, } \\
\text { give, call on }\end{array}$ \\
\hline
\end{tabular}

B. Communication verbs

Communication verbs are a special subcategory of activity verbs that involve communication activities. 
From the collected data, this category is mostly found in news report.

The sentences below are the examples of the use of communication verbs in new articles as the reporting verb.

4. Pavel Hantak, spokesman for the police's organized crime unit (UOOZ), accused the book of promoting a movement suppressing human rights and freedom. (TJP. 300414)

The reporting verb used in data (4) is the verb accuse. This verb means 'to say that somebody has done wrong.' From its meaning, this is clear that this reporting verb belongs to communication verb category because its core meaning is 'say'. In this case, we can conclude that the semantic feature of the word accuse is [say+wrong].

From the types of verb, this verb is included in 'public' type since the activity of verb can be observed publicly. When someone accuses somebody else, the way and the result of his accusing that person will be notified by others.

5. The Meteorology, Climatology and Geophysics Agency (BMKG) announced earlier this month that there was a high possibility of El Niño hitting Indonesia in June or July, which could cause extreme dry weather, leading to harvest failure and fires.(TJP, 300414)

Reporting verb in sentence (5) is the word announce which means make something known publicly. This verb is categorized in communication verb because the activity of this verb has to be delivered verbally. In this sentence, the source of the news, BMKG, is the subject which is capable in giving an announcement related to the wheather and climate discussed in the context of the sentence. As it a communication verb, the activity of the verb is to communicate the message, in this case, the announcement, to the people. The semantic feature that can be concluded for this verb is [say+public].

The type of the verb used here is the public type because the activity of the verb can be publicly observed by the people in the form of announcement given.

6. On the same day in Canberra, Australian Prime Minister Tony Abbott claimed his government's harsh policy against unwanted asylum seekers had drastically reduced the arrival of boat people to Australia. (TJP, 020814)

The reporting verb used in sentence (6) is the word claim. This verb means 'to state or declare something as a fact without being able to prove it'. From its meaning, the verb is given verbally, because the word 'state' or 'declare' are given by speech and therefore this verb is included in communication verb. The semantic feature of this reporting verb is [say+without proof].

The communication verb mentioned in this data belongs to public type since the word claim contain the activity of stating or declaring which can be given publicly and received by public. The subject of the sentence, Australian Prime Minister, also shows that in this sentence, the verb has something to do with the source of the news. From the context of the sentence, the choice of verb used shows that the subject can claim for a policy made and this claim should be publicly shared to the people of the country. 
The reporting verbs found in the news articles which include in communication verb category are listed in table (7).

Table 7: Communication Verbs in News Article

\begin{tabular}{|l|l|}
\hline $\begin{array}{c}\text { Online } \\
\text { News } \\
\text { Media }\end{array}$ & \multicolumn{1}{|c|}{ Communication Verbs } \\
\hline$T J P$ & $\begin{array}{l}\text { say, claim, tell, quote, report, } \\
\text { confirm, refuse, announce, } \\
\text { advise, decline, sentence, } \\
\text { deny, explain, add, agree, } \\
\text { speak, suggest, accuse, } \\
\text { conclude }\end{array}$ \\
\hline$N Y T$ & $\begin{array}{l}\text { say, vow, warn, offer, echo, } \\
\text { impose, decline, insist, argue, } \\
\text { speak, confirm, claim, } \\
\text { interject, agree, make clear, } \\
\text { acknowledge, tell, complain, } \\
\text { call, pledge, ask }\end{array}$ \\
\hline$C N N$ & $\begin{array}{l}\text { say, describe, claim, add, tell } \\
\text { speak, argue, make the } \\
\text { comment, doubt, respond, } \\
\text { make similar assertion, make } \\
\text { similar comment, announce, } \\
\text { ask }\end{array}$ \\
\hline$B B C$ & $\begin{array}{l}\text { say, report, criticise, offer, } \\
\text { tell, suggest, announce, quote, } \\
\text { add, warn, deny }\end{array}$ \\
\hline
\end{tabular}

C. Mental verbs

Mental verbs are verbs which include cognitive meanings and emotional meanings expression various attitudes or desires together with perception and receipt of communication.

The sentences below are the examples of the mental verbs used as reporting verbs in the article.

7. Prosecutors decided that the conduct warranted more than a deferred-prosecution agreement.(NYT, 290414)
Sentence (7) has reporting verb decide which means 'to give a judgment on something'. This verb is categorized as mental verb because the process of giving a judgment occurs in someone's mind. The semantic feature of this verb is [think+judgment] because the verb needs the process of thinking before giving judgment.

According to Quirk (1985), this reporting verb belongs to 'private' type since the process of thinking is unobservable.

\section{The commander thought they might advance. (NYT, 030514)}

The reporting verb in sentence (8) is the verb thought. This verb becomes the core verb for the mental verb since all the activities in mental verbs use the process of thinking. Think means 'use the mind in an active way to form connected ideas'. From this meaning, it is clear that the word think has the process in the mind. Therefore, this verb is also included in the 'private' type since the process is in the mind and cannot be observed by others.

9. The grand mufti weighed whether beheadings could ever be justified by Islam. (CNN, 060215)

The verb weigh in sentence (9) above is the reporting verb used in this sentence. This verb means 'consider something carefully'. In this way, the process of weighing needs careful thinking and this means that this verb includes in mental verb. As the process needs thinking, the semantic feature for this verb is [think+carefully].

Based on the types of the verb proposed by Quirk (1985), this verb 
belongs to 'private' type since the process cannot be observed by others.

Table (8) below lists the reporting verbs in the news articles which include in the category of mental verb.

Table 8: Mental Verbs in News Article

\begin{tabular}{|l|l|}
\hline $\begin{array}{c}\text { Online } \\
\text { News } \\
\text { Media }\end{array}$ & \multicolumn{1}{c|}{ Mental Verbs } \\
\hline$T J P$ & $\begin{array}{l}\text { estimate, expect, decide, } \\
\text { believe }\end{array}$ \\
\hline$N Y T$ & $\begin{array}{l}\text { note, expect, decide, think, } \\
\text { assume, hope }\end{array}$ \\
\hline$C N N$ & weigh, consider, believe \\
\hline$B B C$ & believe, expect \\
\hline
\end{tabular}

\section{CONCLUSION AND SUGGESTION} Conclusion

From the data analysis, it can be concluded that the semantic categories of the reporting verbs found in online news articles are divided into three categories based on the theory of Biber (2002). Those categories are activity, communication, and mental verbs. From these categories, the reporting verbs in the news articles are mostly found in category communication verb. This is inline with the main function of reporting verb which is to convey the language of others.

These categories are therefore subdivided into two types, public and private verbs, following the theory of Quirk (1985), based on whether the process is observable or not by others. From the collected data, the public type is mostly found in the reporting verbs which belong to activity and communication categories.

The next diagram will summarize the semantic categories of the reporting verbs found in online news articles in relation with their semantic features.
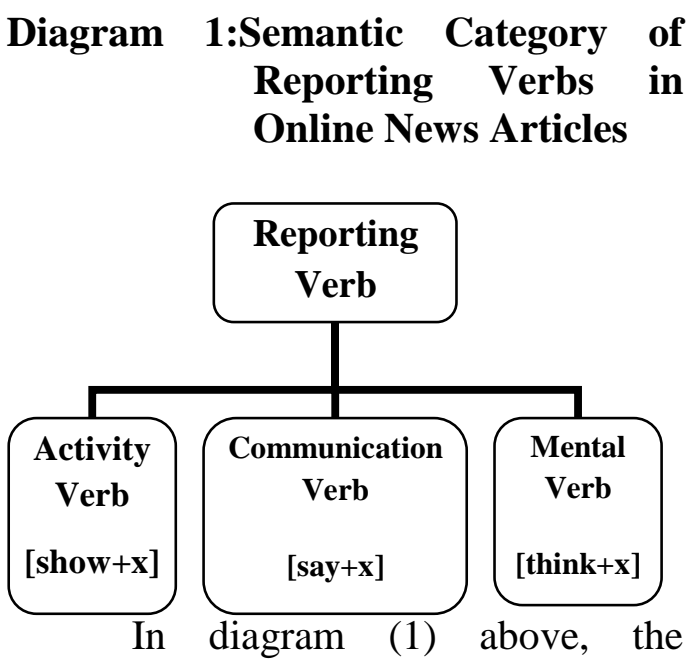

semantic feature of the reporting verbs found is classified into the feature [show $+x]$ for activity verb, $[s a y+x]$ for communication verb, and [think $+x$ ] for mental verb. This means that the core word for the activity verb is from the verb show, the core word for communication verb category is the verb say, and the core word in mental category is the verb think. All these core words are added by some other element to give the specific meaning for each core word.

From all the reporting verbs identified in the data, it can be taken as the conclusion that reporting verb is not only the verb of saying, it can also be in the form of action and mental verbs as long as the verbs are used to convey the message given by the subject as the source of data.

\section{Suggestion}

Reporting verb is not a new term in writing. This feature can be found in every language writing, not to mention in Indonesian writing. However, the problem discussed with this topic is sometimes seen as a less important topic by the Indonesian researchers. Yet, there are actually a lot of things to discuss. Regarding this thing, I would like to suggest other researchers, especially Indonesian researchers, to 
start discussing this kind of verb in Indonesia writing since there is none of the Indonesian researcher focuses on this topic as their subject research.

The topic of the research can be developed in many linguistic fields, such as pragmatics, syntax, and also semantics. The more widely discussion about reporting verbs can also be analyzed through out the discourse analysis or the analysis using systemic functional linguistic approach.

\section{BIBLIOGRAPHY}

Bergler, Sabine. 1992. Evidential Analysis of Reported Speech. Dissertation. Massachusetts. Waltham: Faculty of the Graduate School of Arts\&Sciences of Brandeis University.

Biber, et al. 2002. Longman Student Grammar of Spoken and Written English. Harlow: Longman.

Djajasudarma, Fatimah. 2006. Metode Linguistik: Ancangan Metode Penelitian dan Kajian. Bandung: Refika Aditama.

Een, J. A. 1982. Tense Usage in the Reporting of Past Research in Geotechnical Writing. Minnesota Working Papers in ESL. Minneapolis, Minn: University of Minnesota.

Hanania, E. \& Akhtar, K. 1985. Verb Forms and Rhetorical Function in Science Writing: A Study of MS Theses in Biology, Chemistry and Physics. ESP Journal, 4(1)), p.4558.

Hyland, K. 1999. Academic Attribution: Citation and the Construction of
Disiplinary Knowledge. Applied Linguistics, 20(3), p.341-67.

Kakavoulia, Maria \& Politis, Periklis. 2010. Indirect Discourse in Greek News Articles: Voices and Reporting Verbs. Glossologla, 18, p. 11-24.

Malcolm, L. 1987. What Rules Govern Tense Usage in Scientific Articles?English for Specific Purposes, 6, p.31-44.

Murcia, Marianne Celce\& Freeman, Diane Larsen. 1999. The Grammar Book. USA: Heinle\&Heinle Publishers.

Nkansah, Nancy Boahemaa. 2013. Reporting Verbs and Stance in Front Page Stories of Ghanaian Newspapers. English for Specific Purposes World, issu 40, vol. 14, 2013.

Oster, S. 1981. The Use of Tenses in Reporting Past Literature. In Selinker, Tarone, \& Hanzeli, eds. English for Academic and Technical Purposes: Studies in Honour of Louis Trimble. Newburgh House.

Priest, S. H. 1996. Doing Media Research. New Delhi: The Sage Publications.

Quirk, Randolph, et al. 1985. A Comprehensive Grammar of the English Language. London and New York: Longman.

Sakita, Tomoko I. 2002. Discourse Perspectives on Tense Choice in Spoken-English Reporting Discourse. In Guldemann, Tom and Roncador, Manfred von, eds. 
Reported Discourse: A Meeting Ground for Different Linguistic Domains. Amsterdam: John Benjamins Publishing Co.

Shaw, P. 1992. Reasons for the Correlation of Voice, Tense, and Sentence Function in Reporting Verbs. Applied Linguistics, 13(3), p.302-19.

Thomas, S. \& Hawes, T. 1994. Reporting Verbs in Medical Journal Articles. English for Specific Purposes, 13(2), p. 12948.

Thompson, G. \& Ye, Y. 1991. Evaluation in the Reporting Verbs Used in Academic Papers. Applied Linguistics, 12(4), p.36582.

Weissberg, R. \& Buker, S. 1990. Writing up Research: Experimental Research Report Writing for Students of English. Prentice Hall.

Yamashita, Toru. 1998. Contrastive Analysis of Discourse Representation in Japanese and American Newspaper Reports. Intercultural Communication Studies VIII-2, 1998-9, p. 177191.

Zhang, Xiaoli. 2008. A Contrastive Study of Reporting in Master's Theses in Native Chinese and in Native English. Dissertation. The University of Edinburgh.

Oxford Advanced Learner's Dictionary of Current English, fourth edition. Hornby, A.S. 1994. Oxford: Oxford University Press. 
IJurnal al-Tsaqafa Volume 13, No. 01, Januari 2016

Halaman sengaja untuk dikosongkan 